\title{
RESEARCH
}

Open Access

\section{Mesenchymal stem cells transfected with sFgl2 inhibit the acute rejection of heart transplantation in mice by regulating macrophage activation}

Chao Gao ${ }^{1,2+}$, Xiaodong Wang ${ }^{3+}$, Jian Lu ${ }^{1,2+}$, Zhilin Li ${ }^{1,2}$, Haowen Jia ${ }^{1,2}$, Minghao Chen ${ }^{1,2}$, Yuchen Chang ${ }^{1,2}$, Yanhong Liu ${ }^{1,2}$, Peiyuan $\mathrm{Li}^{1,2}$, Baotong Zhang ${ }^{1,2}$, Xuezhi Du ${ }^{1}$ and Feng $\mathrm{Qi}^{1,2^{*}}$ (i)

\begin{abstract}
Background: Mesenchymal stem cells (MSCs) have become a promising candidate for cell-based immune therapy for acute rejection (AR) after heart transplantation due to possessing immunomodulatory properties. In this study, we evaluated the efficacy of soluble fibronectin-like protein 2 (sFgl2) overexpressing mesenchymal stem cells (sFgl2MSCs) in inhibiting AR of heart transplantation in mice by regulating immune tolerance through inducing M2 phenotype macrophage polarization.
\end{abstract}

Methods and results: The sFgl2, a novel immunomodulatory factor secreted by regulatory $T$ cells, was transfected into MSCs to enhance their immunosuppressive functions. After being co-cultured for $72 \mathrm{~h}$, the sFgl2-MSCs inhibited M1 polarization whereas promoted M2 of polarization macrophages through STAT1 and NF-KB pathways in vitro. Besides, the sFgl2-MSCs significantly enhanced the migration and phagocytosis ability of macrophages stimulated with interferon- $\gamma$ (IFN- $\gamma$ ) and lipopolysaccharide (LPS). Further, the application potential of sFgl2-MSCs in AR treatment was demonstrated by heterotopic cardiac transplantation in mice. The tissue damage and macrophage infiltration were evaluated by H\&E and immunohistochemistry staining, and the secretion of inflammatory cytokines was analyzed by ELISA. The results showed that sFgl2-MSCs injected intravenously were able to locate in the graft, promote the M2 polarization of macrophages in vivo, regulate the local and systemic immune response, significantly protect tissues from damaging, and finally prolonged the survival time of mice heart grafts.

Conclusion: sFgl2-MSCs ameliorate AR of heart transplantation by regulating macrophages, which provides a new idea for the development of anti-AR treatment methods after heart transplantation.

Keywords: MSC-based therapy, Soluble fibrinogen-like protein 2, Macrophage, Heart transplantation, Acute rejection

\footnotetext{
* Correspondence: qifengtmu2017@163.com

${ }^{\dagger}$ Chao Gao, Xiaodong Wang and Jian Lu contributed equally to this work.

'Department of General Surgery, Tianjin Medical University General Hospital,

No. 154 Anshan Road, Heping District, Tianjin 300052, China

${ }^{2}$ Tianjin General Surgery Institute, Tianjin 300052, China

Full list of author information is available at the end of the article
}

(C) The Author(s). 2020 Open Access This article is licensed under a Creative Commons Attribution 4.0 International License, which permits use, sharing, adaptation, distribution and reproduction in any medium or format, as long as you give appropriate credit to the original author(s) and the source, provide a link to the Creative Commons licence, and indicate if changes were made. The images or other third party material in this article are included in the article's Creative Commons licence, unless indicated otherwise in a credit line to the material. If material is not included in the article's Creative Commons licence and your intended use is not permitted by statutory regulation or exceeds the permitted use, you will need to obtain permission directly from the copyright holder. To view a copy of this licence, visit http://creativecommons.org/licenses/by/4.0/ The Creative Commons Public Domain Dedication waiver (http://creativecommons.org/publicdomain/zero/1.0/) applies to the data made available in this article, unless otherwise stated in a credit line to the data. 


\section{Introduction}

In the past decades, organ transplantation has become a primary therapeutic approach in the treatment for endstage heart failure $[1,2]$. At present, the worldwide median survival time of transplanted heart has been greatly increased due to improvements in immunosuppressive treatments [3]. However, acute rejection (AR), which hazards the survival of both allografts and recipients, is still one of the main causes of heart transplantation failure $[4,5]$. Common therapies including pulse steroid therapy, alteration of immunosuppressants, monoclonal antibodies, and combinations have been used to reduce rejection and induce immune tolerance [6]. However, a high dose of steroids and immunosuppressants might lead to a high risk of infection and other side effects [7]. This fact has prompted the development of new immunosuppressive agents designed to reduce the incidence and severity of rejection.

The importance of innate immunity is not negligible in transplant rejection $[8,9]$. Macrophages are the first defense line against foreign matter. As one of the important members of the innate immune system, macrophages are involved in the process of tissue repair [10, 11], as well as rejection or tolerance in early posttransplant inflammation [9, 12-14]. Furthermore, macrophages are characterized by its plasticity and bipolarization, which is commonly differentiated from the primary macrophage (M0) into the classical activated macrophage (M1 phenotype) and alternately activated macrophage (M2 phenotype) under different environmental stimulus $[15,16]$. Therefore, it may have a certain effect on the induction of immune tolerance by promoting the polarization of $\mathrm{M} 2$ macrophage to regulate macrophage function $[8,17,18]$.

Nowadays, mesenchymal stem cells (MSCs) are considered to hold great potential for cell therapy due to their wide source and abilities to repair tissue damage [19-22]. A unique feature of MSCs is that they can accumulate and exert immunomodulatory effects at localized sites of inflammation [22, 23] and induce immune tolerance in organ transplantation [24-26]. Studies have confirmed that MSCs can affect the polarizing of M2 macrophages and promote the phagocytic ability of macrophages, indicating that MSCs play a key role in antigen-stimulated macrophage differentiation [27-29]. Especially, these characteristics can be modified through genetic engineering, which would greatly expand the therapeutic abilities of MSCs [30, 31].

Soluble fibrinogen-like protein 2 ( $\mathrm{sFgl} 2)$ is a novel effector that is mainly secreted by $\mathrm{CD} 4^{+} \mathrm{CD} 25^{+} \mathrm{Foxp} 3^{+}$ Treg cells and tolerogenic $\mathrm{CD} 8^{+} \mathrm{CD} 45 \mathrm{RC}^{\text {low }}$ Treg cells $[32,33]$, which exert coagulation activity and immunosuppressive property $[34,35]$. It was found to be upregulated in a tolerant cardiac and liver transplantation model in mice, which showed the abilities to regulate macrophage functions and inhibit allograft rejection [35, 36]. Therefore, in this study, we constructed a modified MSC overexpressing sFgl2 (sFgl2-MSCs) by gene transfection and explored the regulation of sFgl2-MSCs on macrophages and the protective effects in acute cardiac allograft rejection in mice.

\section{Material and methods}

\section{Experimental animals and ethics statement}

Male C57BL/6J (B6) and BALB/c mice aged 6-8 weeks were purchased from the Laboratory Animal Center of Chinese Academy of Medical Sciences (Beijing, China). The animals were housed and feed under a conventional experimental environment at Tianjin General Surgery Institute (Tianjin, China). All the experiments were following the guidelines from the Institutional Animal Care Committee of Tianjin Medical University General Hospital (Ethical No. IRB2015-YX-009). All efforts were made to minimize animal suffering.

\section{Isolation of MSCs and MO macrophages}

The isolation and purification of MSCs were performed as described [37]. Briefly, subcutaneous adipose tissues of B6 mice were isolated, minced, and transferred into a 50-ml centrifuge tube (Corning, New York, USA) containing $10 \mathrm{ml}$ DMEM/F12 medium (Gibco, MA, USA) under aseptic conditions. The adipose tissues were incubated with type I collagenase $(1 \mathrm{mg} / \mathrm{ml})$ (Solarbio life science, Beijing, China) at $37^{\circ} \mathrm{C}$ for $1.5 \mathrm{~h}$ under shock conditions $(200 \mathrm{rpm})$. The digested adipose tissue was filtered through a $70-\mu \mathrm{m}$ mesh, and the isolated cells were harvested by centrifuging at $1500 \mathrm{rpm}$ for $10 \mathrm{~min}$. The cells were washed with DMEM/F12 medium, centrifuged at $2000 \mathrm{rpm}$ for $10 \mathrm{~min}$, and then resuspended in a complete medium containing DMEM/F12 medium (Corning, New York, USA) supplemented with 10\% fetal bovine serum (FBS) (Hyclone, Logan, UT, USA) and 1\% antibiotic cocktail (Solarbio life science, Beijing, China). The cells were seeded at a density of $1 \times 10^{7} /$ well in a 6 well tissue culture-treated polystyrene (TC-PS) plate (Conning, New York, USA) and cultured at $37^{\circ} \mathrm{C}$ in an incubator (Thermo Fisher Scientific, MA, USA) with 5\% $\mathrm{CO}_{2}$. The culture medium was replaced every $48 \mathrm{~h}$. The phenotype of MSCs was identified with CD34, CD29, CD90, CD45, CD44, and CD105 antibodies (BioLegend, CA, USA) by flow cytometry with a FACS Calibur (BD, Heidelberg, Germany).

To isolate murine bone marrow-derived M0 macrophages, the bilateral femurs and tibia of $\mathrm{C} 57$ mice were removed, followed by careful removal of the supraosseous muscle tissue. Both ends of the mouse bone were cut with an aseptic scissor. The femur marrow cavity was rinsed with serum-free RPMI-1640 medium using a 
1-ml sterile syringe, and the washing liquid was collected into a $15-\mathrm{ml}$ centrifuge tube. The liquid was centrifugated at $1500 \mathrm{rpm}$ for $10 \mathrm{~min}$. The supernatant was aspirated, and the sediment was resuspended with RPMI1640 medium (Corning, New York, USA) containing $10 \%$ FBS to obtain isolated cells. The cells were sorted with a CD14 ${ }^{+}$monocyte isolation kit (Miltenyi Biotec, Bergisch Gladbach, Germany) following the manufacturer's recommendations. The $\mathrm{CD} 14^{+}$monocytes were seeded at a density of $1 \times 10^{7} /$ well into 6 -well TC-PS plates and cultured with RPMI-1640 medium containing $10 \%$ FBS and $20 \mathrm{ng} / \mathrm{ml}$ macrophage colony stimulating factor (M-CSF) (Biolegend, San Diego, CA, USA) with $5 \% \mathrm{CO}_{2}$ at $37^{\circ} \mathrm{C}$ for $24 \mathrm{~h}$. The unattached cells were collected, reinoculated in a $10-\mathrm{cm}$ TC-PS culture plate (Conning, New York, USA), and cultured for 7 days to obtain M0 macrophages. The medium was changed on the fourth day.

\section{Transfection of sFgl2 into MSCs}

The sFgl2-recombinant lentivirus was constructed by Genchem company (Shanghai, China). MSCs of the second generation were seeded in a 6-well plate at a density of $2 \times 10^{5} /$ well and cultured until reached $60 \%$ fusion. The culture medium was changed to 1 -ml viral transfection medium [multiplicity of infection $(\mathrm{MOI})=200$ ], which was consisting of $100 \mu \mathrm{l}$ polybrene $(5 \mu \mathrm{g} / \mathrm{ml})$ and $800 \mu \mathrm{l}$ enhanced infection solution (ENI) (Genchem, Shanghai, China) and $100 \mu \mathrm{l}$ sFgl2-recombinant lentivirus $\left(8 \times 10^{6} \mathrm{TU} / \mu \mathrm{l}\right)$. After incubation at $37^{\circ} \mathrm{C}$ for $10 \mathrm{~h}$, the transfection medium was replaced with the complete medium. Three days later, the stably transfected MSCs (sFgl2-MSCs) were screened by $2 \mu \mathrm{g} / \mathrm{ml}$ puromycin (Solarbio life science, Beijing, China). The expression of sFgl2 in MSCs was evaluated by the enzyme-linked immunosorbent assay (ELISA) kit (Biolegend, San Diego, CA, USA) according to the manufacturer's instructions. The absorbance was measured at $450 \mathrm{~nm}$ by using a Microplate Reader (Tecan, Männedorf, Switzerland).

\section{Evaluation of the cellular behaviors of macrophages in vitro}

To explore the effects of sFgl2-MSCs on the cellular behaviors of macrophages, the M0 macrophages were cocultured with un-transfected MSCs (WT-MSCs), MSCs transfected with negative control virus (negative control MSCs, MSCs-NC), and sFgl2-MSCs. The 24-well transwell chamber with $0.4-\mu \mathrm{m}$ pores was used in the coculture system (Corning, New York, USA). The M0 macrophages were seeded in the lower chamber at a density of $1 \times 10^{5} /$ well, and WT-MSCs, MSCs-NC, and sFgl2-MSCs were seeded in the upper chamber respectively $\left(1 \times 10^{5}\right.$ cells/well). The macrophages treated with $1 \mu \mathrm{g} / \mathrm{ml}$ ciclosporin A (CsA) were used as positive control. Moreover, $1 \mu \mathrm{g} / \mathrm{ml}$ lipopolysaccharide (LPS; Sigma-Aldrich, St. Louis, USA) and $20 \mathrm{ng} / \mathrm{ml}$ interferon$\gamma$ (IFN- $\gamma$; Sigma-Aldrich, St. Louis, USA) were used for the activation of macrophages in vitro.

For macrophage polarization assay, the macrophages that co-cultured for $72 \mathrm{~h}$ were harvested and labeled with fluorescent-conjugated anti-CD206 and anti-CD16/ CD32 antibodies (Biolegend, San Diego, CA, USA) respectively. The cells were analyzed by the flow cytometer. Negative controls were applied to remove background noise and to confirm positive cells.

After being co-cultured for $72 \mathrm{~h}$, the apoptosis of macrophages was analyzed with a Live/Dead Molecular Probes staining kit (Dojindo, Kumamoto, Japan) following the manufacturer's instructions. Briefly, the cells were digested by trypsin, washed with phosphate buffer saline (PBS), incubated with Annexin V-FITC and propidium iodide (PI) at $37^{\circ} \mathrm{C}$ for $30 \mathrm{~min}$, and analyzed by flow cytometry.

For macrophage phagocytosis assay, the expression of CD163, a molecule participating in phagocytosis, was assessed by flow cytometry. Besides, the macrophages that co-cultured for $72 \mathrm{~h}$ were harvested and treated with RPMI-1640 medium containing 10\% FBS and 100 ng/ $\mu$ FITC-labeled ovalbumin (FITC-OVA; Dakewe, Beijing, China) at $37^{\circ} \mathrm{C}$ for $40 \mathrm{~min}$. After washing with PBS for three times, the proportion of FITC-positive cells was analyzed by the flow cytometer.

For macrophage migration assay, the macrophages that co-cultured for $72 \mathrm{~h}$ were digested, resuspended with serum-free 1640 medium, and seeded at a density of $5 \times 10^{4}$ cells into the upper chamber of an $8-\mu \mathrm{m}$ pore size transwell (Conning, New York, USA). Then, $600 \mu \mathrm{L}$ RPMI-1640 medium containing 20\% FBS was added into the lower well. After incubation at $37^{\circ} \mathrm{C}$ for $12 \mathrm{~h}$, the cells migrated through the transwell and stained with $0.1 \%$ crystal violet for $20 \mathrm{~min}$. The migrated cells were photographed using an inverted microscope (Olympus, Tokyo, Japan). The migrated cells were counted with ImageJ software, and 5 random fields per well were obtained for the statistical results.

\section{Quantitative real-time PCR (qPCR)}

Total RNAs of the samples were isolated using the Absolutely RNA Microprep kit (Agilent Technologies, Santa Clara, CA, USA). Total cDNA was synthesized by the High Capacity cDNA Reverse Transcription Kit (Thermo Fisher Scientific, Waltham, MA, USA). The qPCR was performed by using SYBR green qPCR mix (Invitrogen, Carlsbad, CA, USA) on a light cycler instrument (Bio-Rad Laboratories, Hercules, CA, USA). The sequences of primers were as follows: STAT1, forward: 5'-GCTCCATACCCTGAGCCG-3', reverse: 5' TTCCGTTCCCACGTAGACTTA-3'; ІкB, forward: 5' - 
TGACCATGGAAGTGATTGGTCAG-3', reverse: 5' GATCACAGCCAAGTGGAGTGGA-3'; p65, forward: 5'-AGCGAGGCATTAGTGAGATTG-3', reverse: 5' GTCGGTTTCGTGAAGGAGATT-3'; and GAPDH, forward: 5' -ATGGTGAAGGTCGGTGTGAAC-3', reverse: 5 ' -TGTAGTTGAGGTCAATGAAGG-3'.

\section{Western blot}

Total protein was extracted using RIPA lysate contained phosphate inhibitors (Solarbio, Beijing, China) (50:1 V/V) and phenylmethanesulfonyl fluoride (PMSF) (50:1 V/V). Forty micrograms of total protein per sample was subjected to $10 \%$ sodium dodecyl sulfate-polyacrylamide gel electrophoresis (SDS-PAGE), and the proteins were transferred to polyvinylidene fluoride membranes (Merck Millipore, Hayward, CA, USA). Monoclinic antibodies for detecting STAT1 (1:1000), Phospho-STAT1 (1:1000), ІкB (1:1000), Phospho-ІкB (1:1000), NF-кB p65 (1:1000), Phospho-NF- $\kappa B$ p65 (1:1000), and $\beta$-actin (1:2000) (Cell Signaling Technology, Danvers, MA, USA) were added to the membranes respectively and incubated at $4{ }^{\circ} \mathrm{C}$ overnight. The membranes were washed and incubated with the diluted secondary horseradish peroxidase (HRP)marked antibodies (1:2000) (Cell Signaling Technology, Danvers, MA, USA) respectively at room temperature for $2 \mathrm{~h}$. Images were captured by Bio-Rad gel imaging instrument and analyzed with Quantity One (version 4.6; BioRad Laboratories, Hercules, CA, USA).

\section{Heart transplantation}

Intra-abdominal heterotopic cardiac transplantation was performed as previously described [38]. Briefly, donors' hearts were obtained from Balb/c or B6 mice and transplanted to B6 recipients in the abdominal cavity by microsurgical technique. Heart transplantation from B6 to $\mathrm{B} 6$ mice were treated as homologous control (HMC) group. Heart transplantation from Balb/c to B6 was treated as heterogeneous group (HTC). Graft functions were judged by trans-abdominal palpation every day.

\section{Recipient mice treatment}

The mice after heterogeneous heart transplantation were divided into 5 groups. The heterologous control group (HTC) was treated with saline only for 7 days intravenously. For the CsA treatment group (CsA), CsA was dissolved in saline, and the mice were given caudal vein injection with diluted CsA solution $[0.5 \mathrm{mg} /(\mathrm{kg}$ day $)] 24$ $\mathrm{h}$ before surgery and 15 days after surgery. Thereafter, the CsA solution was administered through the caudal vein 3 times per week. For the stem cell treatment groups, $1 \times 10^{6}$ MSCs were transformed into the mice by intravenous injection respectively on the following day after heart transplantation. The samples of serums, cardiac grafts, and spleens of the HTC group were collected on the 7th day, whereas those of treatment groups were collected on the 14th day after the surgery for further analysis.

\section{The localization and functional analysis of sFgl2-MSCs}

The MSCs were digested and adjusted to $1 \times 10^{5} / \mathrm{ml}$ with Hanks' Balanced Salt Solution (HBSS). Then the cell suspensions were inoculated into a 24-well plate. The cells were stained with the $2-\mathrm{nmol} / \mathrm{ml}$ Cell Tracker $^{\mathrm{rm}}$ CM-DiI (Invitrogen, Carlsbad, CA, USA) according to the instructions and adjusted to $1 \times 10^{6} / \mathrm{ml}$. On the 3rd day after injection, the recipient mice were sacrificed to obtain cardiac grafts, and the tissues were quickly frozen into liquid nitrogen. After being frozen for $20 \mathrm{~min}$, the samples were cut into $6-\mu \mathrm{m}$ sections with a refrigerated microtome (Leica, Wetzlar, Germany). The slices were observed immediately under a fluorescence microscope (Olympus Corporation, Hachioji, Tokyo, Japan).

On the 14th day after injection, the expressions of sFgl2 in the serums and cardiac grafts of recipient mice were detected by the ELISA kits (BioLegend, CA, USA) according to the manufacturer's instructions.

\section{Evaluation of AR of recipient mice}

The transplanted cardiac grafts were collected and fixed in 4\% paraformaldehyde, embedded in paraffin, sliced into 4$\mathrm{mm}$-thick sections, and then stained by hematoxylin and eosin (H\&E) to assess the severity of rejection. The slices are photographed under a light microscopy (Olympus Corporation, Hachioji, Tokyo, Japan).

The spleen samples of B6 recipient mice were collected, grinded, and filtered through a 100-mesh screen to obtain a homogeneous cell suspension. The red blood cells were lysed by red blood cell lysis solution (Beyotime Biotechnology, Shanghai, China), and then the splenocytes were washed, centrifuged, suspended, and analyzed with fluorescent-conjugated anti-CD4, anti-CD25, anti-Foxp3, and anti-TIGIT antibodies (eBioscience, San Diego, California, USA) by flow cytometry.

The expression levels of IFN- $\gamma$; tumor necrosis factor (TNF)- $\alpha$; interleukin (IL)-1 $\beta$, IL-4, IL-6, IL-10, IL-12; and transforming growth factor (TGF)- $\beta 1$ in the supernatants of recipients' serum were detected by the ELISA kits (Dakewe Bioengineering, China) according to the manufacturer's instructions. The absorbance was measured at $450 \mathrm{~nm}$ by using a Microplate Reader (Tecan, Männedorf, Switzerland).

\section{Evaluation of the macrophage polarization in vivo}

The spleen samples of B6 recipients were collected, grinded, and filtered through a 100-mesh screen to obtain a homogeneous cell suspension. The red blood cells were lysed by red blood cell lysis solution (Beyotime Biotechnology, Shanghai, China), and then the splenocytes 
were washed, centrifuged, suspended, and labeled with fluorescent-conjugated anti-CD68, anti-CD206, and antiCD16/CD32 antibodies (Biolegend, San Diego, CA, USA) respectively. The cells were analyzed by the flow cytometer.

For immunohistochemical analysis, the sections of transplanted cardiac grafts were incubated with polyclonal primary antibodies: anti-inducible nitronic oxide synthase (iNOS) (1:100, Abcam, Cambridge, UK) and anti-arginase 1 (Arg-1) (1:100, Cell Signaling Technology, Danvers, MA, USA) respectively. Nonspecific staining was assessed by negative control sections, which omitted the primary antibodies. The quantification was done by ImageJ (version 1.51; National Institutes of Health, USA).

\section{Statistical analysis}

The statistical analyses were performed with SPSS 21.0 (IBM SPSS, Chicago, USA). One-way analysis of variance (ANOVA) was used for group comparisons. Data were expressed as mean \pm standard deviations (mean $\pm \mathrm{SD}$ ). The Kaplan-Meier method was used to analyze overall survival. The results were considered significant when $P<0.05$.

\section{Results}

\section{The secretion of $\mathrm{sFgl} 2$ by sFgl2-MSCs}

The MSCs isolated from B6 mice performed a fibroblast-like morphology on the TC-PS surface (Additional file 1, Figure S1A) and were confirmed to be positive for CD29, CD90, CD44, and CD105 and negative for CD34 and CD45 by flow cytometry assay before use (Additional file 1, Figure S1B). The MSCs were transfected with the sFgl2-recombinant lentivirus (Fig. 1a). When the sFgl2-MSCs were passaged to the 10th generation, the expression level of sFgl2 was still stable (Fig. 1b). As shown in Fig. 1c, sFgl2 was definitely secreted in sFgl2-MSCs $(745.59 \pm 13.31 \mathrm{ng} / \mathrm{ml})$ but hardly secreted in WT-MSCs and MSCs-NC. Further, the secretion capacity of sFgl2-MSCs was not affected in the simulated inflammatory medium, i.e., DMEM/F12 medium containing $10 \% \mathrm{FBS}, 25 \mathrm{ng} / \mathrm{ml} \mathrm{IL}-1 \beta, 50 \mathrm{ng} / \mathrm{ml}$

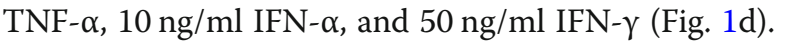

\section{The sFgl2-MSCs promoted the polarization of macrophages to M2 phenotype through JAK-STAT and NF-kB pathways in vitro}

The isolated $\mathrm{CD} 14^{+}$murine bone marrow-derived macrophages (M0) were identified by a microscope and by flow cytometry (Additional file 1, Figure S1C to S1E). To evaluate the effects of sFgl2-MSCs on the polarization of macrophages, the expression of CD16/32 (M1) and CD206 (M2) in macrophages was detected. As shown in Fig. $2 \mathrm{a}$, there was no significant difference between the proportions of $\mathrm{CD} 16 / 32^{+}$cells and $\mathrm{CD} 206^{+}$cells in the CsA group and those in the control group. After being co-cultured with MSCs, the proportion of $\mathrm{CD}_{20}{ }^{+}$cells were increased approximately 5 times compared with the control and CsA groups, and the number of CD206 cells in the sFgl2-MSCs group $(11.04 \pm 1.15 \%)$ was slightly higher than that in the WT-MSCs and MSCs$\mathrm{NC}$ groups (10.54 $\pm 0.73 \%$ and $10.87 \pm 0.60 \%$, respectively). With the stimulation of LPS+IFN- $\gamma$, most of the M0 macrophages in the control group were polarized to M1 phenotype $(91.23 \pm 0.93 \%)$. The incubation with CsA downregulated this proportion to $89.90 \pm 2.31 \%$, whereas the co-culture with WT-MSCs and MSCs-NC further reduced the proportion to $68.73 \pm 2.08 \%$ and $69.93 \pm$ $2.91 \%$ respectively, indicating that MSCs were able to more effectively regulate the polarization of macrophages compared with CsA. Especially, the proportion of $\mathrm{CD}^{206^{+}}$cells in the sFgl2-MSCs group was $69.57 \pm$ $3.91 \%$, which was significantly increased compared with the other groups. These results suggested that the sFgl2MSCs would have a stronger ability to promote the polarization of macrophages to M2 phenotype under inflammatory conditions.

The JAK-STAT and NF- $\mathrm{kB}$ signals derived from IFN- $\gamma$ and LPS receptors play important roles during
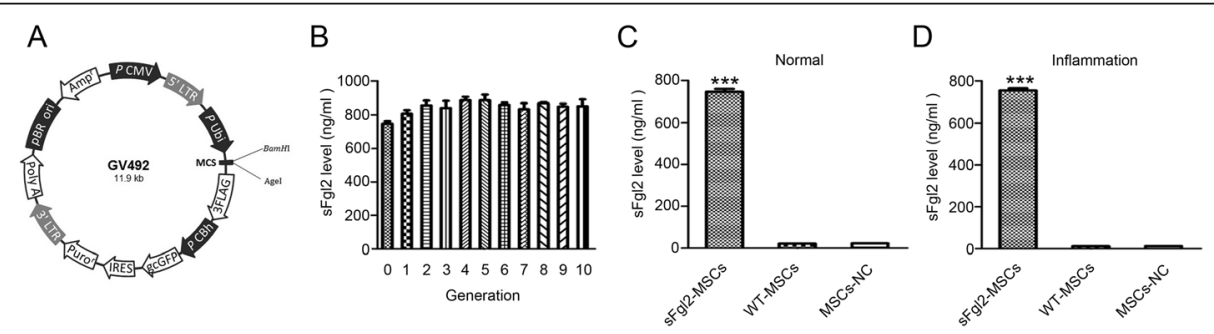

Fig. 1 Construction of MSCS transfected with sFgl2-recombinant lentivirus. a The cDNA that coded for sFgl2 were cloned into the expression vector GV492. The sequence was consisted of 5'-LTR (promoter sequence) -Ubi-MCS-3FLAG-CBh-gcGFP-IRES-puromycin-3'-LTR-polyA (termination sequence). $\mathbf{b}$ The secretion of sFgl2 by the sFgl2-MSCs passaged to the 1st to 10th generation was detected by ELISA. c The secretions of sFgl2 by the WT-MSCs, MSCs-NC, and sFgI2-MSCs cultured with DMEM/F12 medium containing 10\% FBS were detected by ELISA. d The secretions of sFgl2 by the WT-MSCS, MSCS-NC, and SFgI2-MSCs cultured with simulated inflammatory medium were detected by ELISA. The data were reported as mean $\pm \mathrm{SD}, n=3$. ${ }^{* *}$ Significant difference, $P<0.001$ 
A
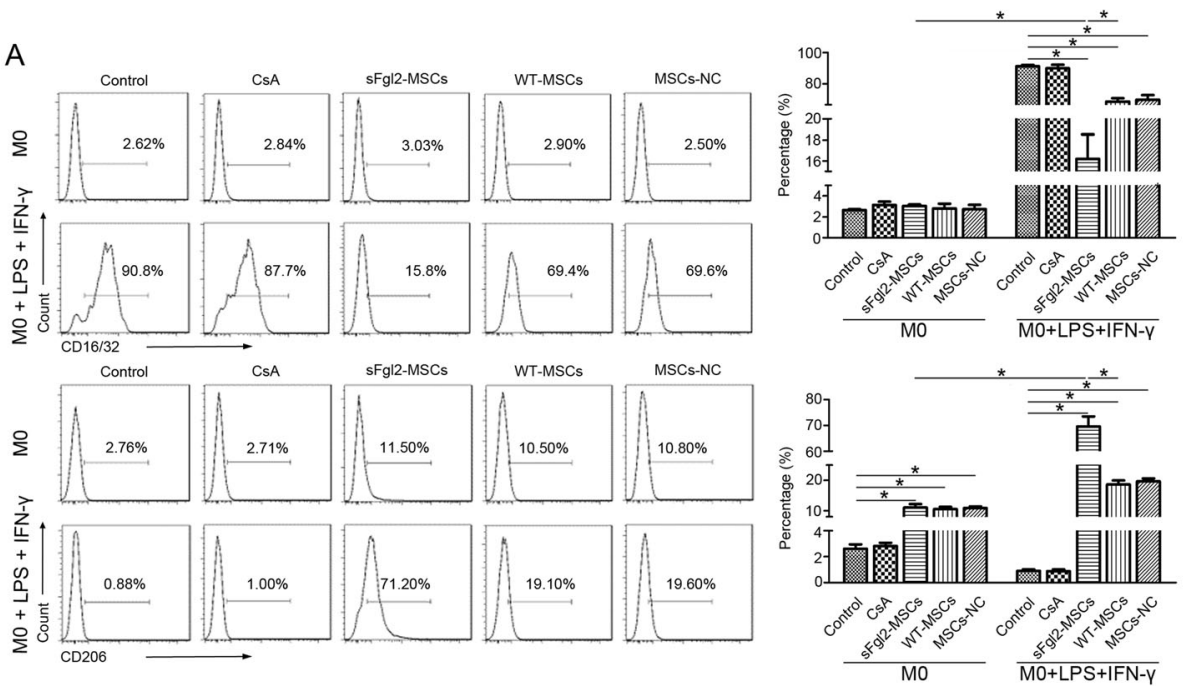

B

C

$\mathrm{D}$
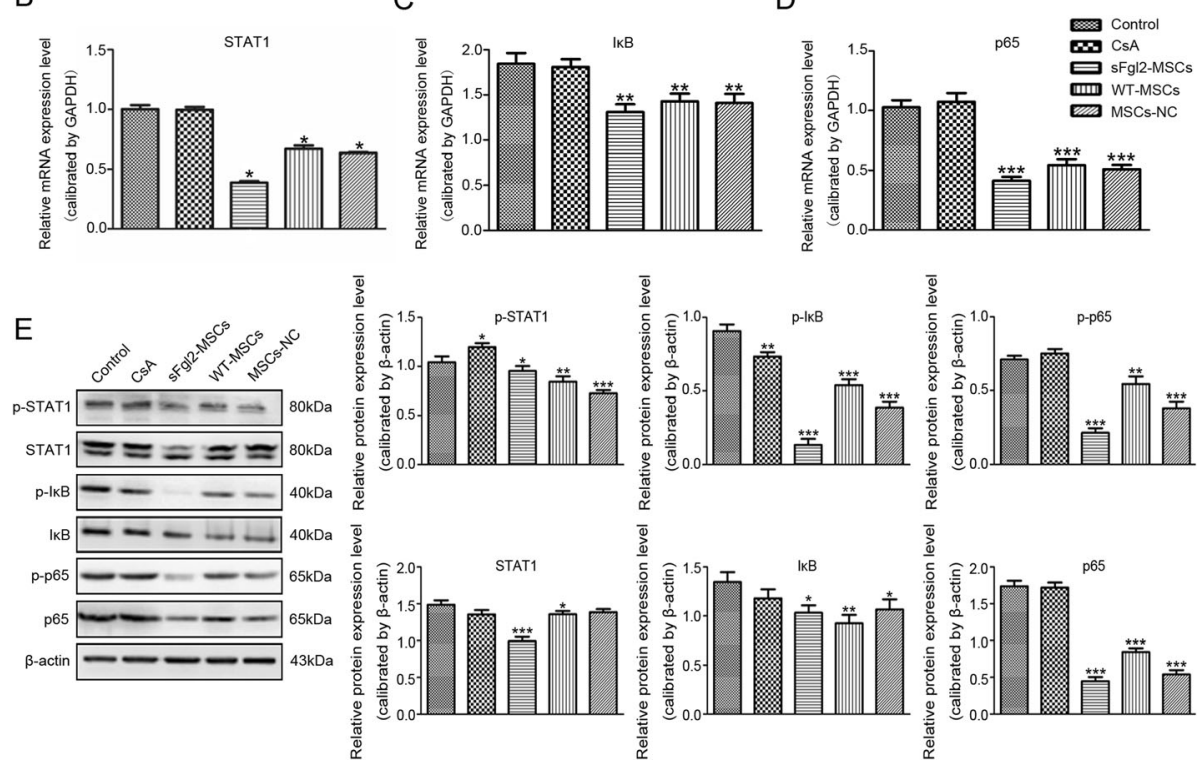

Fig. 2 The effects and related mechanism of sFgl2-MSCs on the polarization of macrophages. a Flow cytometry analysis of CD16/32 and CD206 expressions of macrophages cultured alone, cultured with CsA, or co-cultured with WT-MSCs, MSCs-NC, and sFgl2-MSCs with or without the stimulation of LPS+IFN- $\gamma$ respectively for $72 \mathrm{~h}$. $\mathbf{b}$ - $\mathbf{d}$ The mRNA expression of STAT1, IKB, and p65 in the macrophages cultured alone, cultured with CSA, or co-cultured with WT-MSCS, MSCs-NC, and sFgl2-MSCs with the stimulation of LPS+IFN- $\gamma$ respectively for $72 \mathrm{~h}$. e The phosphorylation and total protein expressions of STAT1, IKB, and p65 in the macrophages cultured alone, cultured with CSA, or co-cultured with WT-MSCs, MSCs$\mathrm{NC}$, and sFgl2-MSCs with the stimulation of LPS+IFN- $\gamma$ for $72 \mathrm{~h}$. The data were reported as mean $\pm \mathrm{SD}, n=3$. * Significant difference, $P<0.05$; **significant difference, $P<0.01$; ${ }^{* *}$ significant difference, $P<0.001$

macrophage polarization $[39,40]$. Besides, it has been reported that $\mathrm{sFgl} 2$ could ameliorate AR in liver transplantation by inhibiting the activities of STAT1 and NF$\kappa B$ signaling pathways [41]. Here, we examined the effect of sFgl2-MSCs on regulating these pathways in the LPS+IFN- $\gamma$-induced macrophage polarization by qPCR and western blot. As shown in Fig. $2 \mathrm{~b}$ to $d$, the mRNA expressions of STAT1, IкB, and NF- $\kappa$ B p65 were significantly downregulated in macrophages co-cultured with MSCs compared with the macrophages cultured alone (control group) and those treated with CsA. Among them, the decrease in the sFgl2-MSCs group was the most obvious. Moreover, the differential expressions of STAT1, IкB, and p65 were validated by western blot (Fig. 2e). The co-culture with sFgl2-MSCs significantly inhibited the phosphorylation of I $\mathrm{kB}$ and p 65 compared with the other groups.

These results suggest that sFgl2-MSCs could promote the polarization of macrophages to M2 phenotype through inhibiting the expression and phosphorylation 
of STAT1 in JAK-STAT pathway, as well as the expression and phosphorylation of $\mathrm{I} \kappa \mathrm{B}$ and $\mathrm{p} 65$ in NF-kB pathway.

\section{The sFgl2-MSCs regulated the cellular behaviors of macrophages}

The apoptosis of macrophages after being co-cultured with sFgl2-MSCs was evaluated by flow cytometry. As shown in Fig. 3a, the stimulation by IFN- $\gamma+$ LPS significantly promoted the apoptosis of macrophages in all groups. However, there was no significant change in the proportion of macrophage apoptosis between the control group $(8.56 \pm 0.18 \%)$ and the treatment groups (CsA $8.51 \pm 0.10 \%, \quad$ sFgl2-MSCs $8.36 \pm 0.20 \%, \quad$ WT-MSCs $8.33 \pm 0.03 \%$, MSCs-NC $8.45 \pm 0.20$ ).

The expression of scavenger receptor CD163 was closely related to the phagocytosis capacity of macrophages [42]. After being co-cultured with MSCs, the proportion of $\mathrm{CD} 163^{+}$macrophages were significantly increased compared with those in the control and CsA groups (Fig. 3b). Although the proportion of $\mathrm{CD} 163^{+}$ macrophages in the sFgl2-MSCs group was slightly higher than that in the other MSC-treated groups, the difference was not statistically significant. The stimulation by IFN- $\gamma+$ LPS attenuated the expression of CD163 in all groups except for the sFgl2-MSCs. In contrast, the proportion of $\mathrm{CD}_{163}{ }^{+}$cells in the sFgl2-MSCs group increased to $66.73 \pm 1.44 \%$, which was significantly higher than those in other groups.

The phagocytosis of macrophages was evaluated with OVA-FITC. The flow cytometer detected the FITC fluorescent signals taken up by macrophages. The results showed that (Fig. 3c) there was no significant change between the CsA-treated group $(39.33 \pm 1.23 \%)$ and the control group $(36.3 \pm 4.54 \%)$. The proportions of FITC $^{+}$ cells in the sFgl2-MSCs, WT-MSCs, and MSCs-NC groups were $46.93 \pm 1.02 \%, 45.6 \pm 3.09 \%$, and $45.7 \pm$ $1.55 \%$, respectively, and there was no statistically significant difference between them. When stimulated by LPS+IFN- $\gamma$, the proportions of FITC $^{+}$cells decreased to $27.8 \pm 1.95 \%$ and $30.47 \pm 2.51 \%$ in the control and CsA groups, whereas those in the WT-MSCs and MSCs-NC groups were $36.0 \pm 1.06 \%$ and $36.3 \pm 2.71 \%$, respectively. The proportion of $\mathrm{FITC}^{+}$cells in the sFgl2-MSCs group was $58.53 \pm 2.50 \%$ which was the highest among these groups. This finding was consistent with the expression trend of CD163.

Moreover, the migration ability of macrophages cocultured with MSCs was evaluated by the transwell experiment. As shown in Fig. 3d, the migration efficiency of macrophage cells co-cultured with MSCs was significantly enhanced compared with those in the non-cocultivation groups. The number of macrophage cells that migrated through the transwell chamber in the sFgl2-
MSCs group was the highest among these groups without stimulation with LPS+IFN- $\gamma$, and the migration ability was further promoted in the presence of LPS + IFN $-\gamma$ stimulation.

These results indicated that the sFgl2-MSCs were more responsive to inflammatory microenvironment compared with unmodified MSCs and significantly enhanced the migration and phagocytosis ability of macrophages.

\section{The sFgl2-MSCs inhibited AR after heart transplantation}

To explore the effect of sFgl2-MSCs on AR of heart transplantation, we established a mouse intra-abdominal heterotopic cardiac transplantation model with the recipient receiving sFgl2-MSCs treatment. As shown in $H \& E$ staining images of the allografts (Fig. 4a), the untreated group suffered the severest rejection, characterized by myocyte necrosis, interstitial hemorrhage, lymphocyte infiltration, vasculitis, and intravascular thrombosis. The AR in the WT-MSCs and MSCs-NC groups was slightly worse than in the HTC group. However, after treatment with CsA or sFgl2-MSCs, no myocyte necrosis, tissue swelling, and vasculitis were found in the allografts, while only a small number of lymphocytes infiltrated into the tissue, indicating that sFgl2MSCs and CsA treatment could significantly alleviate AR after heart transplantation. Consistently, the overall survival of recipients receiving sFgl2-MSCs and CsA treatment (52.0 \pm 10.67 days and $58.83 \pm 7.67$ days $)$ was significantly longer than that in the control, WT-MSCs, and MSCs-NC groups $(8.33 \pm 0.52$ days, $15.3 \pm 1.03$ days, and $15.7 \pm 0.82$ days, respectively) (Fig. $4 \mathrm{~b}$ ). In addition, in the sFgl2-MSCs treatment group, the survival times of several mice were even more than 60 days.

To evaluate the effect of sFgl2-MSCs, treatment on the immune tolerance after heart transplantation was evaluated by using the percentage of both regulatory $\mathrm{T}$ cells (Tregs) and TIGIT ${ }^{+}$Tregs in the spleen of allograft recipients on days 7 and 14 after heart transplantation. As shown in Fig. 4c-e and Additional file 2 Figure S2, the percentages of Tregs $\left(\mathrm{CD} 25^{+} \mathrm{Foxp} 3^{+}\right.$cells in $\mathrm{CD} 4^{+}$ gating population) and $\mathrm{TIGIT}^{+}$Tregs $\left(\mathrm{CD} 25^{+} \mathrm{Foxp}^{+}{ }^{+} \mathrm{TI}-\right.$ $\mathrm{GIT}^{+}$cells in $\mathrm{CD}^{+}$gating population) in the sFgl2MSCs group were both significantly higher than those in the other groups. Furthermore, the expression levels of pro-inflammatory cytokines and anti-inflammatory cytokines in the serum of mice in each group were detected by ELISA on days 7 and 14 after heart transplantation. The results (Fig. 4f) demonstrated that all of the treatments, including CsA and MSCs, were able to decrease the levels of pro-inflammatory cytokines (IFN- $\gamma$, TNF- $\alpha$, IL-6, IL-12, and IL-1 $\beta$ ) in the serum on the 7th day after the operation. On day 14, the serum levels of the proinflammatory cytokines in the WT-MSCs and MSCs-NC 


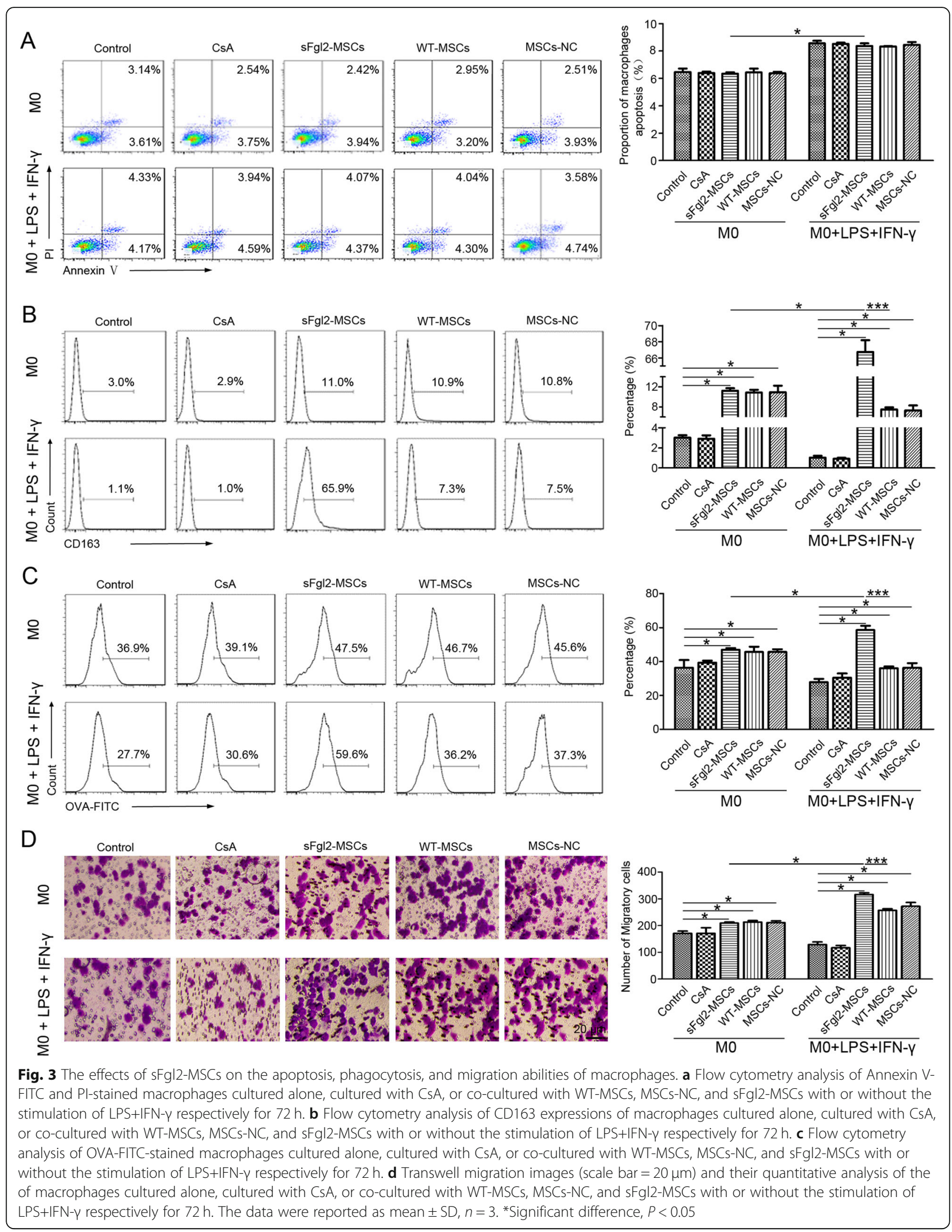



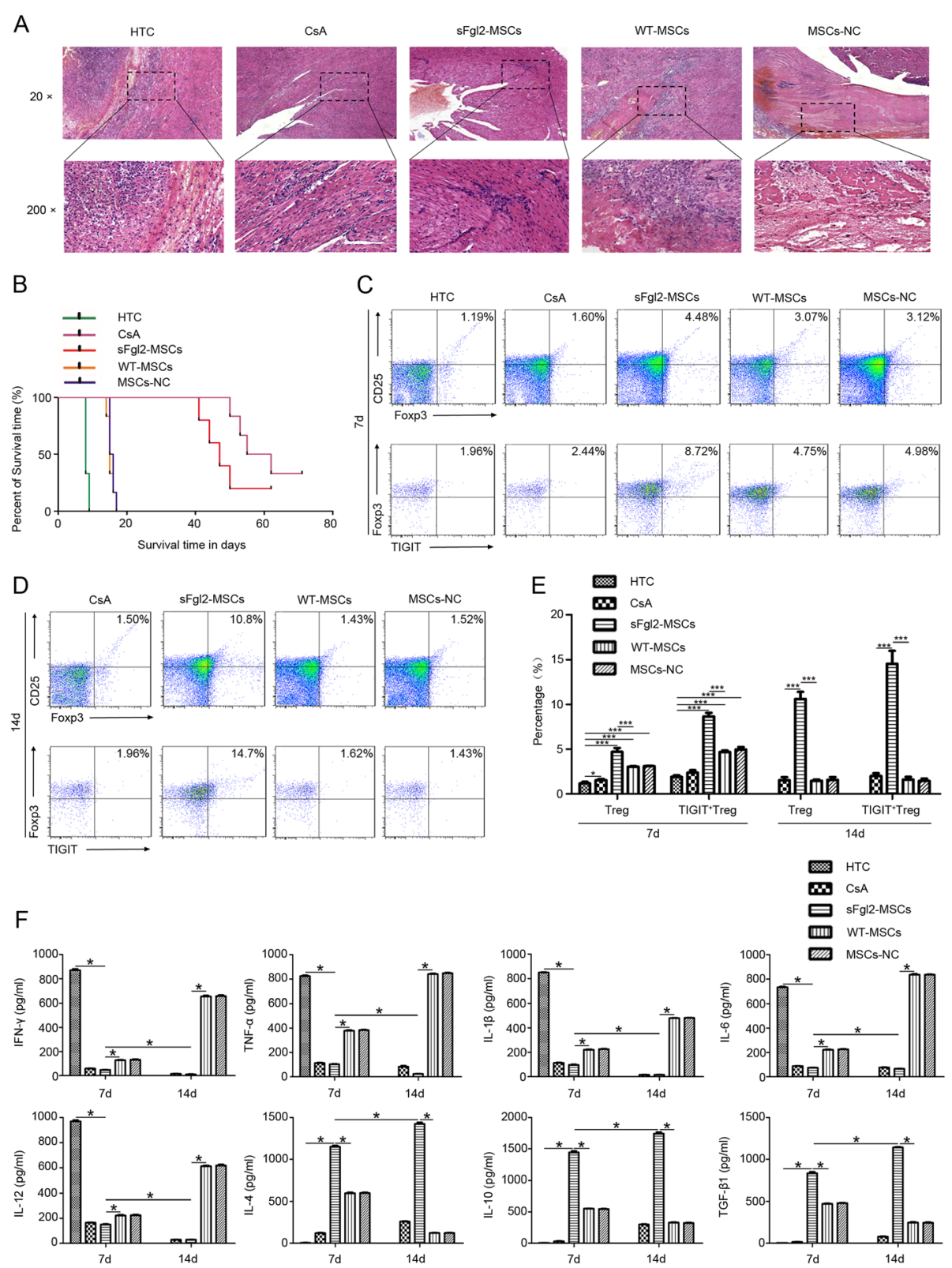

Fig. 4 The effects of sFgl2-MSCs on the AR treatment after heart transplantation. a H\&E staining images $(\times 20$ and $\times 200)$ of allografts on day 7 in all groups. b Kaplan-Meier curve performed the survival of recipients. c-e Flow cytometry analysis of CD4-FITC, CD25-APC, and Foxp3-Percp-cy5.5 (Treg) and TIGIT-PE (TIGIT Treg)-stained splenocytes isolated from the spleen samples of recipient mice was performed on day 7 in all groups and on day 14 in the CSA, WT-MSCs, MSCs-NC, and sFgI2-MSCs groups. f The expression levels of IFN- $\gamma$, TNF- $\alpha$, IL-1 $\beta$, IL-6, IL-12, IL-4, IL-10, and TGF- $\beta 1$ in the supernatants of recipients' serum were detected on day 7 in all groups and on day 14 in the CsA, WT-MSCs, MSCs-NC, and sFgl2-MSCs groups after heart transplantation. The data were reported as mean $\pm \mathrm{SD}, n=3$. ${ }^{*}$ Significant difference, $P<0.05$; ${ }^{* *}$ significant difference, $P<0.001$

groups were significantly elevated, while those were decreased in the CsA and sFgl2-MSCs groups. It is worth noting that the levels of pro-inflammatory cytokines in sFgl2-MSCs were always the lowest among these groups. Meanwhile, the levels of antiinflammatory factors, including IL-4, IL-10, and TGF$\beta 1$, in the sFgl2-MSCs, WT-MSCs, and MSCs-NC groups were significantly higher than those in the
HTC group on day 7, and those in the WT-MSCs and MSCs-NC groups were all decreased on day 14 . Among the MSC groups, the levels of IL-4, IL-10, and TGF- $\beta 1$ in the sFgl2-MSCs group were the highest on day 7 and showed a trend of continuous increase from 7 to 14 days. However, IL-4, IL-10, and TGF- $\beta 1$ cytokines in the CsA group were all at a low level on days 7 and 14 . 
As shown in Figure S3A-B (Additional file 3), the injected MSCs were able to locate in the cardiac grafts on the 3rd day after treatment, and the expressions of sFgl2 were able to be detected from both cardiac grinding fluid and serum only in the sFgl2-MSCs group on the 14th day after treatment. These results suggested that sFgl2-MSCs were able to secrete sFgl2 in vivo for at least 14 days, inhibited AR, and induced immune tolerance after heart transplantation by not only exerting their general immune regulatory functions aside of secreting sFgl2, but also homing to the cardiac graft.

\section{The sFgl2-MSCs promoted the polarization of macrophages in vivo}

Macrophage accumulation has long been recognized as a feature of allograft rejection [43]. Here, the essential role of macrophage infiltration in AR after heart transplantation was firstly confirmed by detecting the subsets and proportion of macrophage in the $\mathrm{B} 6$ mice that received the heart transplantation from Balb/c mice (the heterogeneous transplantation group, HTC) and from B6 mice (the homologous transplantation group, HMC).

As shown in Figure S4A (Additional file 4), in the HTC group, i.e., the AR group, the proportion of $\mathrm{CD} 68^{+} \mathrm{CD} 16 /$ $32^{+}$cells (M1 macrophages) on days 1,3 , and 7 was $3.24 \pm$ $0.18 \%, 6.41 \pm 0.36 \%$, and $11.8 \pm 0.34 \%$, respectively, whereas that in HMC group was $1.18 \pm 0.04 \%(P<0.05)$. Meanwhile, the proportion of $\mathrm{CD} 68^{+} \mathrm{CD} 206^{+}$cells (M2 macrophages) in the HTC group on days 1,3 , and 7 was $3.46 \pm 0.30 \%$, $2.51 \pm 0.43 \%$, and $1.81 \pm 0.20 \%$, respectively, which was significantly lower than that in the HMC group $(5.55 \pm 0.26 \%)$. Moreover, the IHC results showed in Figure S4B (Additional file 4) that no infiltration of $\mathrm{iNOS}^{+}$cells (M1 macrophages) as well as several infiltrated ARG- ${ }^{+}$cells (M2 macrophages) were found in the HMC group after the operation. The amount of $\mathrm{iNOS}^{+}$cells continuously increased in HTC groups from day 1 to day 7 after the operation, while the ARG- $1^{+}$cells were basically invisible.

After treatment with WT-MSCs and the MSCs-NC group, a large number of iNOS ${ }^{+}$cell infiltration, and little ARG- $1^{+}$cells were observed in the allografts, which was similar to the macrophage's infiltration in the HTC group (Fig. 5a). However, in the CsA and sFgl2-MSCs groups, the number of $\mathrm{iNOS}^{+}$cells was much fewer than that of the other groups, and obviously, Arg- $1^{+}$staining was able to be found in the allografts. By quantifying positively stained areas, it was found that the infiltration of M1 macrophage in the sFgl2-MSCs group was similar to that in the CsA group, while the infiltration of M2 macrophage in the sFgl2-MSCs group was significantly higher than that in the other groups, except for the CsA group (Additional file 5, Figure S5).

We further evaluated the differences of M1/M2 macrophage proportion in the recipient mice treated with CsA and MSCs; the spleens of mice in each group were collected after the mice were sacrificed on the 7th day and 14th day. The proportion of $\mathrm{CD} 68^{+} \mathrm{CD} 16 / 32^{+}$ (M1) and $\mathrm{CD}^{+} 8^{+} \mathrm{CD} 206^{+}$(M2) macrophages in the spleen tissues were detected. As shown in Fig. 5b, the treatment with CsA and MSCs significantly downregulated the proportion of M1 cells, while upregulated the proportion of M2 cells in the spleen tissues on the day 7 after the operation. The proportion of $\mathrm{CD} 68^{+} \mathrm{CD} 206^{+}$cells in the sFgl2MSCs continuously increased from day $7(6.73 \pm 0.30 \%)$ to day $14(12.53 \pm 0.91 \%)$ (Fig. $5 \mathrm{c})$, which were both higher than the proportion of $\mathrm{CD} 68^{+} \mathrm{CD} 206^{+}$cells in the other groups at the same time point.

In conclusion, the infiltration of M1/M2 macrophages played an important role in the process of AR after heart transplantation. The treatment with sFgl2-MSCs can inhibit AR by not only regulating the infiltration of macrophages into the allografts, but also promoting the M2 polarization of macrophages in the spleen.

\section{Discussion}

In recent decades, the several treatment options, such as pulsed steroid therapy, the use of an antibody preparation, and the alteration of background immunosuppression, have been applied to deal with AR [44]. Over recent years, new treatment strategies have evolved; however, sometimes, organ damage is inevitable [45]. This issue has brought our focus back to innate immunity, whose importance is not negligible in transplant rejection $[8,9]$. Unlike immunosuppressive drugs, cell therapies based on MSCs showed abilities to influence almost all immune components as shown for T cells, B cells, and monocytic and dendritic cells, which bring hope for improving the prognosis of organ transplant [46-50]. In this study, we constructed sFgl2-MSCs through gene transfection to enhance the immunosuppressive functions of MSCs, attempting to improve the prognosis of heart transplantation. It was found that the allografts in the HTC, WT-MSCs, and MSCs-NC groups showed typical tissue injury due to AR, and the treatment with sFgl2-MSCs was able to promote the formation of immune tolerance, reduce the tissue damage induced by AR after heart transplantation, and significantly prolong the survival of recipients (Fig. 4).

As is known, a range of differently activated macrophages (M1 and M2 phenotype) are involved throughout the alloimmune response [13]. The sustained activation of M1 macrophages would lead to tissue injury, while the M2 macrophages can possess anti-inflammatory functions and facilitate wound healing as well as angiogenesis [14]. When AR occurs, the macrophages infiltrate the graft responding to donor antigens and subsequently give rise to inflammation, increased myocytolysis, myocardial edema, and myocyte necrosis [51]. 


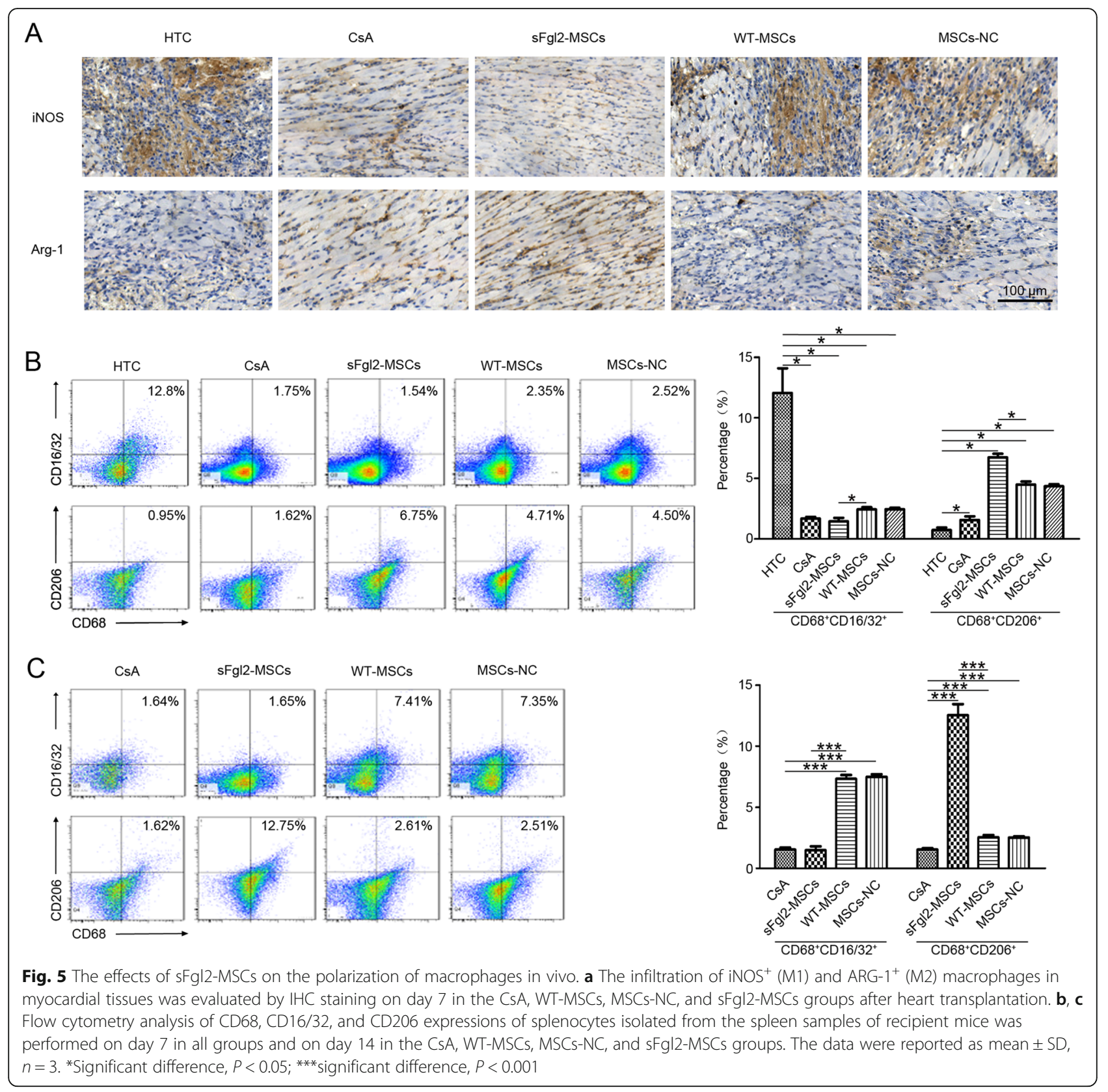

Here, the treatment with sFgl2-MSCs continuously upregulated the proportion of M2 macrophages in the spleen tissues during the 14 days after the operation and elevated the number of M2 macrophages infiltrated into the allografts (Fig. 5). These results suggested that the sFgl2-MSCs were able to regulate the activation of macrophages systemically, and alter the behaviors of macrophages at the local levels. It has been reported that promoting M2 macrophage polarization is beneficial to inhibit immune rejection and prolong graft survival [37, 52-54]. Therefore, we believed that these changes in macrophage phenotype were beneficial to inhibit the acute rejection of heart transplantation.
Cytokines, soluble factors, and cell surface or matrixbound ligands may all engage specific macrophage receptors and promote the polarization of macrophages [55]. The MSCs can be passively recognized by monocytes through a cell-cell interaction in the sepsis model, while the immunomodulation in the treatment of allogenic heart transplantation seemed more dependent on their secretory function [56]. Our results showed that, compared with the WT-MSCs and MSCs-NC groups, the sFgl2-MSCs inhibited M1 phenotype polarization whereas promoted M2 phenotype of polarization macrophages and significantly enhanced the migration and phagocytosis ability of macrophages under the 
stimulation with IFN- $\gamma$ and LPS. It was reported that MSCs were able to induce the M2-like macrophage differentiation by soluble molecules acting partially via glucocorticoid and progesterone receptors [57] and program the plasticity of macrophage by altering their metabolic status via a PGE2-dependent mechanism [58]. In addition, the macrophage activation induced by sFgl2-MSCs should be strongly related to their secretion of sFgl2.

There are extensive studies demonstrating that sFgl2 acts on macrophages through the special receptors of FcyRIIb and FcyRIII, but its downstream pathways in macrophages are still unclear [59]. Here, we reported for the first time that the sFgl2-MSCs inhibited the expression and phosphorylation of STAT1 in JAK-STAT pathway, as well as I $\mathrm{B}$ and $\mathrm{p} 65$ in NF- $\kappa \mathrm{B}$ pathway in macrophages when stimulated with IFN- $\gamma$ and LPS. NF- $k B$ is an important signaling molecule that regulates macrophage polarization [60]. Moreover, the STAT1 ADP-ribosylation was proved to be involved in the activation of macrophages regulated by PARP9 and PARP14 [61]. Pan et al. reported that sFGL2 could induce the M2 polarization of Kupffer cells by suppressing the STAT1 and NF-kB signaling pathway [41]. However, the specific role of STAT1 and NF- $\mathrm{kB}$ pathways active by sFgl2-MSCs in regulating the polarization, phagocytosis, and migration in macrophages still needs further confirmation.

As one of the widely used immunosuppressive agents, CsA has provided great progress in transplantation. However, its high dose and long-term usage have adverse reactions including renal and liver dysfunction as well as neurotoxicity, which could limit further clinical application [62, 63]. In recent years, MSCs were proven to have immune suppressive properties and actively contribute to tissue repair in inflammatory diseases and organ transplantation [64, 65]. The MSC-based therapeutic approaches have been used in clinical trials and pre-clinical trials and can be accepted by patients who underwent transplantation [47, 66-68]. Furthermore, MSC monotherapy or MSCs in combination with CsA could reduce the dose of immunosuppressive agents. The previous study in our laboratory confirmed that the median survival time (MST) of mesenchymal-like stromal cells-endometrial regenerative cell (ERC) monotherapy-is $19.67 \pm 2.58$ days, while the MST of the immunosuppressive therapy group is $19.83 \pm 3.19$ days (data not shown), which indicate that both of the treatments are similar in extending the survival time of the allografts in the study [69]. The study also revealed that the combination of ERCs with immunosuppressive therapy induces donor-specific tolerance in vivo. Therefore, it is a safe and effective treatment for rejection after transplantation [70-74]. In addition, MSCs have a wide range of sources, due to their easy isolation and propagation and lower immunogenicity and tumorigenicity, which could be promising therapeutic applications for preventing clinical transplantation rejection and for reducing negative effects of immunosuppressants in the future $[65,68,72,74]$.

\section{Conclusion}

In summary, sFgl2-MSCs constructed in this study have showed better therapeutic effect on AR after heart transplantation in mice by regulating macrophage activation. The sFgl2-MSCs significantly promote M2 macrophage polarization and inhibit M1 macrophage polarization in vitro and in vivo, which might be related to suppressing the STAT1 and NF- $\mathrm{kB}$ signaling pathways. Although the mice in the CsA- and sFgl2-MSCs-treated groups survived for nearly 60 days, most of the heart grafts lost function within 30 days. With a view to further improve the therapeutic effect of sFgl2-MSCs, we would further optimize their application strategies to promote the effects of sFgl2-MSCs on immune tolerance inducement in the follow-up study.

\section{Supplementary information}

Supplementary information accompanies this paper at https://doi.org/10. 1186/s13287-020-01752-1.

Additional file 1 : Figure S1. Characteristics of the isolated MSCs and M0 macrophages. A The morphology of the cells isolated from the subcutaneous adipose tissues of B6 mice. B Flow cytometry analysis of CD34, CD29, CD90, CD45, CD44 and CD105 expressions of the cells isolated from the subcutaneous adipose tissues of B6 mice. C, D The morphology of the macrophages isolated from the femur marrow of C57 mice. E Flow cytometry analysis of CD14 expressions of the macrophages isolated from the femur marrow of C57 mice.

Additional file $\mathbf{2}$ : Figure S2. Evaluation of the percentage of regulatory $\mathrm{T}$ cells (Tregs) and $\mathrm{TIGIT}^{+}$Tregs in spleen of allograft recipients. For the Tregs, the percentage of CD25 ${ }^{+}$Foxp $^{+}$cells in CD4+ gating population was determined by fluorescence-activated cell sorting analysis. For the $\mathrm{TIGIT}^{+}$Tregs, CD25 ${ }^{+} \mathrm{Foxp}^{+}{ }^{\mathrm{TIGIT}}{ }^{+}$cells in $\mathrm{CD}^{+}$gating population was determined by fluorescence-activated cell sorting analysis. A Dot plots of $\mathrm{CD}^{+} \mathrm{T}$ cells. B Dot plots of $\mathrm{CD} 4^{+} \mathrm{CD} 25^{+} \mathrm{Foxp} 3^{+} \mathrm{T}$ cells and $\mathrm{CD}^{+} \mathrm{CD}^{2} 5^{+} \mathrm{Foxp}^{+} \mathrm{TIGIT}^{+} \mathrm{T}$ cells.

Additional file $\mathbf{3}$ : Figure S3. The location and SFGL2 secretion of sFgl2-MSCs after injected into mice. A The CM-Dil staining (red) of WTMSCs, MSCs-NC and sFgl2-MSCs located in the cardiac grafts of on the 3rd day after MSC treatment. B The expressions of sFgl2 in the serums and cardiac grinding fluids the recipient mice. The data were reported as mean $\pm S D, n=3$. ${ }^{*}$ Significant difference, $P<0.01$; *** Significant difference, $P<0.001$.

Additional file 4 : Figure S4. Evaluation of the construction of mice intra-abdominal heterotopic cardiac transplantation model. A Flow cytometry analysis of CD68, CD16/32 and CD206 expressions of splenocytes isolated from HMC mice on day 7 and $\mathrm{HTC}$ mice on day 1, 3, 7 after transplantation. B The infiltration of iNOS ${ }^{+}$(M1) and ARG-1 ${ }^{+}(\mathrm{M} 2)$ macrophages in myocardial tissues were evaluated by $\mathrm{HC}$ staining on day 7 in HMC group and on day 1, 3, 7 in HTC group after transplantation.

Additional file $\mathbf{5}$ : Figure S5. The quantification of the $\mathrm{IHC}$ staining of iNOS and ARG-1 in myocardial tissues of the recipient mice. The data were reported as mean $\pm S D, n=3$. ${ }^{* *}$ Significant difference, $P<0.001$.

\section{Abbreviations}

MSCs: Mesenchymal stem cells; AR: Acute rejection; sFgl2: Soluble fibronectin-like protein 2; DMEM: Dulbecco's modified Eagle medium; 
EDTA: Ethylenediaminetetraacetic acid; qPCR: Quantitative real-time polymerase chain reaction; ELISA: Enzyme-linked immunosorbent assay; FBS: Fetal bovine serum; MOI: Multiplicity of infection; ENI: Enhanced infection solution;

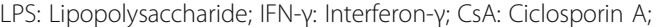
OVA: Ovalbumin; Arg-1: Arginase-1; iNOS: Inducible nitric oxide synthase; GAPDH: Glyceraldehyde-phosphate dehydrogenase; HMC: Homologous control; HTC: Heterogeneous control; HE: Hematoxylin and eosin; IL: Interleukin; TNF-a: Tumor necrosis factor-a; M-CSF: Macrophage colony stimulating factor; M0: Primary macrophages; M1: Classic-activated macrophage; M2: Alternatively activated macrophage; ANOVA: Analysis of variance; SD: Sprague-Dawley

\section{Acknowledgements}

Not applicable.

\section{Authors' contributions}

CG and XW conceived the project design and conception. CG, XW, and JL were responsible for the experimental design and application including data acquisition and analysis. CG and XW wrote and revised the manuscript. XW, $\mathrm{J}$, and $\mathrm{HJ}$ standardized the figures. $X \mathrm{~W}, \mathrm{~J}, \mathrm{HJ}, \mathrm{BZ}$, and $\mathrm{ZL}$ made the model for the manuscript. $M C, Y C, X D, Y L$, and $P L$ contributed to the technique assistance and critically revised the manuscript. FQ provided valuable suggestions for the manuscript. All authors gave final approval of the manuscript and agreed to be accountable for all aspects of the work.

\section{Funding}

This work was supported by The National Natural Science Foundation of China (grant number 81570375), Tianjin Binhai New Area Health Commission Science-technology Innovation Plan Projects (grant number 2017BWKY036), and "13th Five-Year Plan" Comprehensive Investment Discipline Construction Project of Tianjin Medical University (grant number 116015012016XK0301).

\section{Availability of data and materials}

The datasets used and/or analyzed during the current study are available from the corresponding author on reasonable request.

\section{Ethics approval and consent to participate}

All animal experiments in this study were approved by the Ethics Committee of Tianjin Medical University General Hospital (ethical number IRB2015-YX009), and all experimental procedures were performed in accordance with protocols approved by the Institutional Animal Care and Use Committee and conformed to the Guidelines for the Care and Use of Laboratory Animals published by the US National Institutes of Health.

\section{Consent for publication}

Not applicable.

\section{Competing interests}

The authors declare that they have no competing interests.

\section{Author details}

'Department of General Surgery, Tianjin Medical University General Hospital, No. 154 Anshan Road, Heping District, Tianjin 300052, China. ${ }^{2}$ Tianjin General Surgery Institute, Tianjin 300052, China. ${ }^{3}$ Department of Gastrointestinal Surgery, the First Affiliated Hospital of Medical School of Zhejiang University, Hangzhou 310003, Zhejiang province, China.

Received: 1 April 2020 Revised: 19 May 2020

\section{Accepted: 1 June 2020 Published online: 17 June 2020}

\section{References}

1. Schlendorf KH, Shah AS. Application and interpretation of histocompatibility data in thoracic (heart and lung) transplantation. Curr Opin Organ Transplant. 2017;22:421-5. https://doi.org/10.1097/MOT.0000000000000424.

2. Iske J, Nian Y, Maenosono R, Maurer M, Sauer IM, Tullius SG. Composite tissue allotransplantation: opportunities and challenges. Cell Mol Immunol. 2019;16:343-9. https://doi.org/10.1038/s41423-019-0215-3.

3. Messner F, Etra JW, Dodd-O JM, Brandacher G. Chimerism, transplant tolerance, and beyond. Transplantation. 2019;103:1556-67. https://doi.org/ 10.1097/TP.0000000000002711.
4. Weber BN, Kobashigawa JA, Givertz MM. Evolving areas in heart transplantation. JACC: Heart Failure. 2017;5:869-78. https://doi.org/10.1016/j. jchf.2017.10.009

5. Kobashigawa J, Luu M. Immunosuppression strategies in heart transplantation. Clinical guide to heart transplantation. Cham: Springer; 2017. p. 109-35

6. Kittleson M, Kobashigawa J. Acute rejection. Heart failure. Cham: Springer; 2019. p. 255-9.

7. Kobashigawa J, Luu M. Cardiac allograft rejection, surveillance and treatment. Clinical guide to heart transplantation. Cham: Springer; 2017. p. $157-70$

8. Mori DN, Kreisel D, Fullerton JN, Gilroy DW, Goldstein DR. Inflammatory triggers of acute rejection of organ allografts. Immunol Rev. 2014;258:13244. https://doi.org/10.1111/imr.12146.

9. Béland S, Désy O, Vallin P, Basoni C, De Serres SA. Innate immunity in solid organ transplantation: an update and therapeutic opportunities. Expert Rev Clin Immunol. 2015;11:377-89. https://doi.org/10.1586/1744666x.2015. 1008453.

10. Ben-Mordechai T, Holbova R, Landa-Rouben N, Harel-Adar T, Feinberg MS, Abd Elrahman I, Blum G, Epstein FH, Silman Z, Cohen S, Leor J. Macrophage subpopulations are essential for infarct repair with and without stem cell therapy. J Am Coll Cardiol. 2013;62:1890-901. https://doi.org/10.1016/j.jacc. 2013.07.057.

11. Löffler J, Sass FA, Filter S, Rose A, Ellinghaus A, Duda GN, Dienelt A. Compromised bone healing in aged rats is associated with impaired $\mathrm{M} 2$ macrophage function. Front Immunol. 2019;10:2443. https://doi.org/10.3389/ fimmu.2019.02443.

12. Moreau A, Varey E, Anegon I, Cuturi M. Effector mechanisms of rejection. Cold Spring Harb Perspect Med. 2013;3. https://doi.org/10.1101/cshperspect. a015461.

13. van den Bosch TPP, Kannegieter NM, Hesselink DA, Baan CC, Rowshani AT Targeting the monocyte-macrophage lineage in solid organ transplantation. Front Immunol. 2017:8:153. https://doi.org/10.3389/fimmu.2017.00153.

14. Li J, Li C, Zhuang Q, Peng B, Zhu Y, Ye Q, Ming Y. The evolving roles of macrophages in organ transplantation. J Immunol Res. 2019;2019:5763430. https://doi.org/10.1155/2019/5763430.

15. Murray PJ, Allen JE, Biswas SK, Fisher EA, Gilroy DW, Goerdt S, et al. Macrophage activation and polarization: nomenclature and experimental guidelines. Immunity. 2014;41:14-20. https://doi.org/10.1016/j.immuni.2014. 06.008 .

16. Mosser DM, Edwards JP. Exploring the full spectrum of macrophage activation. Nat Rev Immunol. 2008;8:958-69. https://doi.org/10.1038/nri2448,

17. Kim J, Choi S, Lim BJ, Kim YS, Huh KH, Lee J, Kim SI, Kim MS, Jeong HJ. Clinical significance of macrophage polarization in antibody-mediated rejection of renal allograft. Transplant Proc. 2018;50:1005-8. https:/doi.org/ 10.1016/j.transproceed.2018.02.037.

18. Zhao Y, Chen S, Lan P, Wu C, Dou Y, Xiao X, Zhang Z, Minze L, He X, Chen W, Li XC. Macrophage subpopulations and their impact on chronic allograft rejection versus graft acceptance in a mouse heart transplant model. Am J Transplant. 2018;18:604-16. https://doi.org/10.1111/ajt.14543.

19. Bartholomew A, Sturgeon C, Siatskas M, Ferrer K, McIntosh K, Patil S, Hardy W, Devine S, Ucker D, Deans R, Moseley A, Hoffman R. Mesenchymal stem cells suppress lymphocyte proliferation in vitro and prolong skin graft survival in vivo. Exp Hematol. 2002;30:42-8. https://doi.org/10.1016/s0301472x(01)00769-x

20. Halim N, Ch'ng ES, Kardia E, Ali SA, Radzi R, Yahaya BH. Aerosolised mesenchymal stem cells expressing angiopoietin-1 enhances airway repair. Stem Cell Rev. 2019;15:112-25. https://doi.org/10.1007/s12015-018-9844-7.

21. Liu S. Mesenchymal stem cell engineering. Methods Mol Biol. 1868;2018: 145-50. https://doi.org/10.1007/978-1-4939-8802-0_15.

22. Qi K, Li N, Zhang Z, Melino G. Tissue regeneration: the crosstalk between mesenchymal stem cells and immune response. Cell Immunol. 2018;326:8693. https://doi.org/10.1016/j.cellimm.2017.11.010.

23. Shi Y, Su J, Roberts Al, Shou P, Rabson AB, Ren G. How mesenchymal stem cells interact with tissue immune responses. Trends Immunol. 2012;33:13643. https://doi.org/10.1016/j.it.2011.11.004.

24. Yip H, Lee MS, Sun C, Chen K, Chai H, Sung P, Lin K, Ko S, Yuen C, Liu C, Shao $P$, Lee $F$. Therapeutic effects of adipose-derived mesenchymal stem cells against brain death-induced remote organ damage and post-heart transplant acute rejection. Oncotarget. 2017;8:108692-711. https://doi.org/ 10.18632/oncotarget.21433 
25. Keller C, Erasmus DB, Alvarez F, Mallea J, Hurst KE, David-Robinson HA, Zubair AC. Preliminary report on the effect of mesenchymal stem cell (MSC) infusion in lung function on patients with chronic allograft dysfunction (CLAD). J Heart Lung Transplant. 2016;35:S43. https://doi.org/10.1016/j. healun.2016.01.116.

26. Yu P, Wang Z, Liu Y, Xiao Z, Guo Y, Li M, Zhao M. Marrow mesenchymal stem cells effectively reduce histologic changes in a rat model of chronic renal allograft rejection. Transplant Proc. 2017;49:2194-203. https://doi.org/ 10.1016/j.transproceed.2017.09.038.

27. Yin Y, Hao H, Cheng Y, Zang L, Liu J, Gao J, Xue J, Xie Z, Zhang Q, Han W, Mu Y. Human umbilical cord-derived mesenchymal stem cells direct macrophage polarization to alleviate pancreatic islets dysfunction in type 2 diabetic mice. Cell Death Dis. 2018;9:760. https://doi.org/10.1038/s41419018-0801-9.

28. Jackson MV, Morrison TJ, Doherty DF, McAuley DF, Matthay MA Kissenpfennig A, O'Kane CM, Krasnodembskaya AD. Mitochondrial transfer via tunneling nanotubes is an important mechanism by which mesenchymal stem cells enhance macrophage phagocytosis in the in vitro and in vivo models of ARDS. Stem cells (Dayton). 2016;34:2210-23. https:// doi.org/10.1002/stem.2372.

29. Geng Y, Zhang L, Fu B, Zhang J, Hong Q, Hu J, Li D, Luo C, Cui S, Zhu F, Chen $X$. Mesenchymal stem cells ameliorate rhabdomyolysis-induced acute kidney injury via the activation of M2 macrophages. Stem Cell Res Ther. 2014;5:80. https://doi.org/10.1186/scrt469.

30. Uchida S, Hayakawa K, Ogata T, Tanaka S, Kataoka K, Itaka K. Treatment of spinal cord injury by an advanced cell transplantation technology using brain-derived neurotrophic factor-transfected mesenchymal stem cell spheroids. Biomaterials. 2016;109:1-11. https://doi.org/10.1016/j.biomaterials. 2016.09.007

31. Song SY, Hong J, Go S, Lim S, Sohn HS, Kang M, Jung G, Yoon J, Kang ML, Im G, Kim B. Interleukin-4 gene transfection and spheroid formation potentiate therapeutic efficacy of mesenchymal stem cells for osteoarthritis. Adv Healthc Mater. 2020;9:e1901612. https://doi.org/10.1002/adhm. 201901612.

32. Li XL, Ménoret S, Bezie S, Caron L, Chabannes D, Hill M, et al. Mechanism and localization of CD8 regulatory T cells in a heart transplant model of tolerance. J Immunol. 2010;185:823-33. https://doi.org/10.4049/jimmunol. 1000120.

33. Shalev I, Liu H, Koscik C, Bartczak A, Javadi M, Wong KM, et al. Targeted deletion of fgl 2 leads to impaired regulatory $T$ cell activity and development of autoimmune glomerulonephritis. J Immunol. 2008;180:24960. https://doi.org/10.4049/jimmunol.180.1.249

34. Chan CWY, Chan MWC, Liu M, Fung L, Cole EH, Leibowitz JL, Marsden PA, Clark DA, Levy GA. Kinetic analysis of a unique direct prothrombinase, fgl2, and identification of a serine residue critical for the prothrombinase activity. J Immunol. 2002;168:5170-7. https://doi.org/10.4049/jimmunol.168.10.5170.

35. Marazzi S, Blum S, Hartmann R, Gundersen D, Schreyer M, Argraves S, von Fliedner V, Pytela R, Rüegg C. Characterization of human fibroleukin, a fibrinogen-like protein secreted by T lymphocytes. J Immunol. 1998;161: 138-47

36. Xie L, Ichimaru N, Morita M, Chen J, Zhu P, Wang J, Urbanellis P, Shalev I, Nagao S, Sugioka A, Zhong L, Nonomura N, Takahara S, Levy GA, Li X. Identification of a novel biomarker gene set with sensitivity and specificity for distinguishing between allograft rejection and tolerance. Liver Transpl. 2012;18:444-54. https://doi.org/10.1002/lt.22480.

37. Marín E, Cuturi MC, Moreau A. Tolerogenic dendritic cells in solid organ transplantation: where do we stand. Front Immunol. 2018;9:274. https://doi. org/10.3389/fimmu.2018.00274

38. Yan Y, Zhao N, He X, Guo H, Zhang Z, Liu T. Mesenchymal stem cell expression of interleukin-35 protects against ulcerative colitis by suppressing mucosal immune responses. Cytotherapy. 2018;20:911-8. https://doi.org/10.1016/j.jcyt.2018.05.004

39. Sow FB, Alvarez GR, Gross RP, Satoskar AR, Schlesinger LS, Zwilling BS, Lafuse WP. Role of STAT1, NF-kB, and C/EBP $\beta$ in the macrophage transcriptional regulation of hepcidin by mycobacterial infection and IFN- $\gamma$. J Leukoc Biol. 2009;86:1247-58.

40. Ohmori Y, Hamilton TA. Requirement for STAT1 in LPS-induced gene expression in macrophages. J Leukoc Biol. 2001;69:598-604. https://doi.org/ 10.1189/jlb.69.4.598.

41. Pan G, Zhao Z, Tang C, Ding L, Li Z, Zheng D, Zong L, Wu Z. Soluble fibrinogen-like protein 2 ameliorates acute rejection of liver transplantation in rat via inducing Kupffer cells M2 polarization. Cancer Med. 2018;7:316877. https://doi.org/10.1002/cam4.1528.

42. Fabriek BO, Dijkstra CD, van den Berg TK. The macrophage scavenger receptor CD163. Immunobiology. 2005;210:153-60. https://doi.org/10.1016/j. imbio.2005.05.010

43. Wyburn KR, Jose MD, Wu H, Atkins RC, Chadban SJ. The role of macrophages in allograft rejection. Transplantation. 2005;80:1641-7. https:// doi.org/10.1097/01.tp.0000173903.26886.20.

44. Webster AC, Wu S, Tallapragada K, Park MY, Chapman JR, Carr SJ. Polyclonal and monoclonal antibodies for treating acute rejection episodes in kidney transplant recipients. Cochrane Database Syst Rev. 2017;7:CD004756. https:// doi.org/10.1002/14651858.CD004756.pub4.

45. Plenter RJ, Grazia TJ. Murine heterotopic heart transplant technique. J Vis Exp. 2014. https://doi.org/10.3791/51511.

46. Uccelli A, Moretta L, Pistoia V. Immunoregulatory function of mesenchymal stem cells. Eur J Immunol. 2006;36:2566-73. https://doi.org/10.1002/eji. 200636416.

47. Pistoia V, Raffaghello L. Mesenchymal stromal cells and autoimmunity. Int Immunol. 2017;29:49-58. https://doi.org/10.1093/intimm/dxx008.

48. Marquina M, Collado JA, Pérez-Cruz M, Fernández-Pernas P, Fafián-Labora J, Blanco FJ, Máñez R, Arufe MC, Costa C. Biodistribution and immunogenicity of allogeneic mesenchymal stem cells in a rat model of intraarticular chondrocyte xenotransplantation. Front Immunol. 2017:8:1465. https://doi. org/10.3389/fimmu.2017.01465.

49. Wang $Q$, Sun B, Wang D, Ji Y, Kong Q, Wang G, Wang J, Zhao W, Jin L, Li H. Murine bone marrow mesenchymal stem cells cause mature dendritic cells to promote T-cell tolerance. Scand J Immunol. 2008;68:607-15. https://doi. org/10.1111/j.1365-3083.2008.02180.x.

50. Zhang B, Liu R, Shi D, Liu X, Chen Y, Dou X, Zhu X, Lu C, Liang W, Liao L, Zenke M, Zhao RCH. Mesenchymal stem cells induce mature dendritic cells into a novel Jagged-2-dependent regulatory dendritic cell population. Blood. 2009:113:46-57. https://doi.org/10.1182/blood-2008-04-154138.

51. Wu YL, Ye Q, Ho C. Cellular and functional imaging of cardiac transplant rejection. Curr Cardiovasc Imaging Rep. 2011;4:50-62. https://doi.org/10. 1007/s12410-010-9055-3

52. Wu C, Zhao Y, Xiao X, Fan Y, Kloc M, Liu W, Ghobrial RM, Lan P, He X, Li XC. Graft-infiltrating macrophages adopt an M2 phenotype and are inhibited by purinergic receptor P2X7 antagonist in chronic rejection. Am J Transplant. 2016;16:2563-73. https://doi.org/10.1111/ajt.13808.

53. Li H, Shi B. Tolerogenic dendritic cells and their applications in transplantation. Cell Mol Immunol. 2015;12:24-30. https://doi.org/10.1038/ cmi.2014.52.

54. Wei Y, Zheng D, Li X, Zhou W, Qian Y, Ming C, Shi B. Infusion of dendritic cells carrying donor lymphocytes treated with 8-methoxypsoralen and ultraviolet A light induces CD19+ IL-10+ regulatory B cells and promotes skin allograft survival. Transplant Proc. 2014;46:3641-6. https://doi.org/10. 1016/j.transproceed.2014.09.093.

55. Martinez FO, Gordon S. The M1 and M2 paradigm of macrophage activation: time for reassessment. F1000Prime Rep. 2014;6:13. https://doi.org/ 10.12703/P6-13.

56. Weiss ARR, Lee O, Eggenhofer E, Geissler E, Korevaar SS, Soeder Y, Schlitt HJ, Geissler EK, Hoogduijn MJ, Dahlke MH. Differential effects of heatinactivated, secretome-deficient MSC and metabolically active MSC in sepsis and allogenic heart transplantation. Stem Cells. 2020. https://doi.org/10. 1002/stem.3165.

57. Abumaree $\mathrm{MH}, \mathrm{Al}$ Jumah MA, Kalionis B, Jawdat D, Al Khaldi A, Abomaray FM, Fatani AS, Chamley LW, Knawy BA. Human placental mesenchymal stem cells (pMSCs) play a role as immune suppressive cells by shifting macrophage differentiation from inflammatory M1 to anti-inflammatory M2 macrophages. Stem Cell Rev. 2013;9:620-41. https://doi.org/10.1007/s12015013-9455-2.

58. Vasandan AB, Jahnavi S, Shashank C, Prasad P, Kumar A, Prasanna SJ. Human mesenchymal stem cells program macrophage plasticity by altering their metabolic status via a PGE(2)-dependent mechanism. Sci Rep. 2016;6: 38308. https://doi.org/10.1038/srep38308.

59. Ocaña-Guzman R, Vázquez-Bolaños L, Sada-Ovalle I. Receptors that inhibit macrophage activation: mechanisms and signals of regulation and tolerance. J Immunol Res. 2018;2018:8695157. https://doi.org/10.1155/2018/ 8695157.

60. Jin X, Yao T, Zhou Z, Zhu J, Zhang S, Hu W, Shen C. Advanced glycation end products enhance macrophages polarization into $M 1$ phenotype 
through activating RAGE/NF-KB pathway. Biomed Res Int. 2015;2015:732450 .

61. Iwata H, Goettsch C, Sharma A, Ricchiuto P, Goh WWB, Halu A, et al. PARP9 and PARP14 cross-regulate macrophage activation via STAT1 ADPribosylation. Nat Commun. 2016;7:12849. https://doi.org/10.1038/ ncomms 12849.

62. Wu Q, Wang X, Nepovimova E, Wang Y, Yang H, Kuca K. Mechanism of cyclosporine A nephrotoxicity: oxidative stress, autophagy, and signalings. Food Chem Toxicol. 2018;118:889-907. https://doi.org/10.1016/j.fct.2018.06 054.

63. Rezzani R. Exploring cyclosporine A-side effects and the protective roleplayed by antioxidants: the morphological and immunohistochemical studies. Histol Histopathol. 2006;21:301-16. https://doi.org/10.14670/hh-21. 301.

64. Reinders MEJ, Bank JR, Dreyer GJ, Roelofs H, Heidt S, Roelen DL, Al Huurman V, Lindeman J, van Kooten C, Claas FHJ, Fibbe WE, Rabelink TJ, de Fijter JW. Autologous bone marrow derived mesenchymal stromal cell therapy in combination with everolimus to preserve renal structure and function in renal transplant recipients. J Transl Med. 2014;12:331. https://doi.org/10. 1186/s12967-014-0331-X.

65. Naji A, Eitoku M, Favier B, Deschaseaux F, Rouas-Freiss N, Suganuma N. Biological functions of mesenchymal stem cells and clinical implications. Cell Mol Life Sci. 2019;76:3323-48. https://doi.org/10.1007/s00018-01903125-1.

66. Shi M, Liu Z, Wang Y, Xu R, Sun Y, Zhang M, Yu X, Wang H, Meng L, Su H, Jin L, Wang F. A pilot study of mesenchymal stem cell therapy for acute liver allograft rejection. Stem Cells Transl Med. 2017;6:2053-61. https://doi. org/10.1002/sctm.17-0134.

67. Podestà MA, Remuzzi G, Casiraghi F. Mesenchymal stromal cells for transplant tolerance. Front Immunol. 2019;10:1287. https://doi.org/10.3389/ fimmu.2019.01287.

68. Galipeau J, Sensébé L. Mesenchymal stromal cells: clinical challenges and therapeutic opportunities. Cell Stem Cell. 2018;22:824-33. https://doi.org/10. 1016/j.stem.2018.05.004.

69. Lan X, Wang G, Xu X, Lu S, Li X, Zhang B, Shi G, Zhao Y, Du C, Wang H. Stromal cell-derived factor-1 mediates cardiac allograft tolerance induced by human endometrial regenerative cell-based therapy. Stem Cells Transl Med. 2017;6:1997-2008. https://doi.org/10.1002/sctm.17-0091.

70. Pan G, Chen Z, Xu L, Zhu J, Xiang P, Ma J, Peng Y, Li G, Chen X, Fang J, Guo $Y$, Zhang L, Liu L. Low-dose tacrolimus combined with donor-derived mesenchymal stem cells after renal transplantation: a prospective, nonrandomized study. Oncotarget. 2016;7:12089-101. https://doi.org/10.18632/ oncotarget.7725.

71. Peng Y, Ke M, Xu L, Liu L, Chen X, Xia W, Li X, Chen Z, Ma J, Liao D, Li G Fang J, Pan G, Xiang AP. Donor-derived mesenchymal stem cells combined with low-dose tacrolimus prevent acute rejection after renal transplantation: a clinical pilot study. Transplantation. 2013;95:161-8. https://doi.org/10.1097/ tp.0b013e3182754c53.

72. You Y, Wen D, Gong J, Liu Z. Research status of mesenchymal stem cells in liver transplantation. Cell Transplant. 2019;28:1490-506. https://doi.org/10. 1177/0963689719874786.

73. Casiraghi F, Perico N, Cortinovis M, Remuzzi G. Mesenchymal stromal cells in renal transplantation: opportunities and challenges. Nat Rev Nephrol. 2016; 12:241-53. https://doi.org/10.1038/nrneph.2016.7.

74. Hajkova M, Jaburek F, Porubska B, Bohacova P, Holan V, Krulova M. Cyclosporine A promotes the therapeutic effect of mesenchymal stem cells on transplantation reaction. Clin Sci (Lond). 2019;133:2143-57. https://doi. org/10.1042/cs20190294

\section{Publisher's Note}

Springer Nature remains neutral with regard to jurisdictional claims in published maps and institutional affiliations.

Ready to submit your research? Choose BMC and benefit from:

- fast, convenient online submission

- thorough peer review by experienced researchers in your field

- rapid publication on acceptance

- support for research data, including large and complex data types

- gold Open Access which fosters wider collaboration and increased citations

- maximum visibility for your research: over $100 \mathrm{M}$ website views per year

At BMC, research is always in progress.

Learn more biomedcentral.com/submissions 